Journal of European Public Policy

\title{
Preferences for European unemployment insurance: a question of economic ideology or EU support?
}

\section{Theresa Kuhn, Francesco Nicoli \& Frank Vandenbroucke}

To cite this article: Theresa Kuhn, Francesco Nicoli \& Frank Vandenbroucke (2020) Preferences for European unemployment insurance: a question of economic ideology or EU support?, Journal of European Public Policy, 27:2, 208-226, DOI: 10.1080/13501763.2019.1701529

To link to this article: https://doi.org/10.1080/13501763.2019.1701529
(C) 2020 The Author(s). Published by Informa UK Limited, trading as Taylor \& Francis Group

\section{$+$}

View supplementary material $\widetilde{ }$

曲 Published online: 30 Jan 2020.

\section{Submit your article to this journal $\sqrt{3}$}

\section{凹 Article views: 361}

Q View related articles $\sqsubset$

View Crossmark data $\nearrow$ 


\title{
Preferences for European unemployment insurance: a question of economic ideology or EU support?
}

\author{
Theresa Kuhn (D) ${ }^{\mathrm{a}}$, Francesco Nicoli ${ }^{\mathrm{b}}$ and Frank Vandenbroucke ${ }^{\mathrm{c}}$ \\ aDepartment of Political Science, University of Amsterdam, Amsterdam, The Netherlands; \\ ${ }^{\mathrm{b}}$ Department of Public Governance and Management, University of Gent, Gent, Belgium; \\ 'Amsterdam Institute for Social Science Research (AISSR), University of Amsterdam, \\ Amsterdam, The Netherlands
}

\begin{abstract}
Against the backdrop of proposals to introduce a European unemployment insurance scheme, we study public support for such schemes by conducting a conjoint experiment on support for European unemployment insurance in 13 EU member states. We argue that European-level social policy initiatives and the underlying notions of solidarity cannot be reduced to a one-dimensional concept, but rather include various dimensions. Unemployment schemes vary in their generosity, the conditions for support, their impact on taxation, the extent to which they preclude permanent redistribution between countries, and the EU's role in their administration. Generosity, conditions and taxation are 'domestic' dimensions, since they mainly resonate with domestic policy debates; between-country redistribution and administration are 'cross-border' dimensions, referring to relationships between countries. We expect economic ideology to interact predominantly with domestic dimensions and EU support to interact predominantly with cross-border dimensions. Findings confirm these expectations, with the exception of between-country redistribution and country-level conditionality.
\end{abstract}

KEYWORDS European unemployment insurance; European social policy; economic left-right orientations; support for European integration; solidarity; conjoint analysis

\section{Introduction}

In the aftermath of the euro crisis, policy makers started to discuss the creation of solidarity mechanisms at the European level. The rationale for this is twofold: first, these mechanisms would ease economic adjustment in the Economic and Monetary Union (EMU), second, they would ensure social protection for citizens of crisis-struck countries. Although governments remain divided, the idea that EMU needs an automatic mechanism of risk sharing 
to absorb unemployment shocks has been discussed both in the European Commission (2017a, 2017b) and the European Council (Van Rompuy 2012). The euro crisis has also increased the political salience of European integration, and public opinion has become an increasingly relevant factor in legitimizing further integration (Hooghe and Marks 2018).

Hence, it is key to understand what European citizens make of these plans to establish a European unemployment insurance (EUI) and how different design features of risk sharing contribute to support for such policies. This paper focuses on how individuals' economic ideology and attitudes towards European integration affect preferences for alternative proposals for EUI. Existing research yields mixed results by showing that both economic ideology (Kleider and Stoeckel 2018) and attitudes towards European integration (Bechtel et al. 2014; Kleider and Stoeckel 2018; Kuhn et al. 2018) play an important role in structuring public support for cross-border solidarity.

We argue that European-level social policy initiatives and the underlying notions of solidarity cannot be reduced to a single, one-dimensional concept of what 'social Europe' or 'European solidarity' entails (Baute et al. 2018; Gallego and Marx 2017). For instance, EUI includes various dimensions, such as the generosity and conditionality of the scheme, and citizen support for EUI likely depends on these dimensions. We expect that economic ideology and attitudes towards European integration influence the impact of the various policy dimensions on policy support in different ways. We show that some dimensions, such as generosity, are 'domestic' dimensions, since they mainly resonate with domestic policy debates and hence relate more directly to the economic ideology of respondents, whereas preferences over other dimensions, such as administration of the scheme, are 'cross-border' dimensions, referring to relationships between countries and reflect citizens' orientations towards European integration. We conducted a conjoint survey experiment involving 19,500 respondents across 13 EU countries. We ask respondents to choose between randomly assigned pairs of policy packages, varying across six dimensions: (1) their generosity (the minimum level of benefits secured by European support); (2) whether there are conditions for participating countries in terms of providing education and training for the unemployed; (3) whether the scheme involves permanent between-country redistribution; (4) the impact of the scheme on taxation in the respondent's country; (5) whether the scheme is administered by the EU or by national governments; (6) whether there are conditions attached for the individual unemployed. We aim to reflect important dimensions of existing policy proposals and to study differences in political attitudes. We consider generosity, conditions and taxation as predominantly 'domestic' dimensions, since they mainly resonate with well-known domestic policy debates. In contrast, we consider between-country redistribution and the level of administration 
as 'cross-border' dimensions, since they refer to relationships between countries.

We find that only about $3 \%$ of the respondents reject all forms of unemployment risk sharing, while about $6 \%$ lend unconditional support to all packages. In general, support for these schemes depends on the design features and on attitudes and background characteristics of the respondents. Supporting our hypotheses, we find that the level of administration, which is a cross-border dimension, has substantially more traction depending on individual attitudes towards European integration; the results for the other cross-border dimension, between-country redistribution, point to some extent in the same direction, but the results are less straightforward. We find that domestic dimensions have substantially more traction depending on the individual's economic ideology, except for the conditions that apply to the education and training programmes which the countries have to provide. The latter observation may be explained by the fact that the leftright cleavage does not play out in domestic debates on training and education in the way it plays out in domestic debates on, for instance, the generosity of benefits, or by the fact that the distinction between 'domestic' and 'cross-border' is less clear-cut with regard to this dimension.

\section{Public support for European unemployment risk sharing}

The European Commission has argued repeatedly that, next to a Banking Union and a Capital Market Union, EMU needs automatic fiscal stabilizers (Franchino and Segatti 2019). One option to achieve this would be the reinsurance of national unemployment benefit schemes at the euro-zone level (European Commission 2017a, 2017b). The organization of automatic stabilizers, such as a re-insurance of national unemployment benefits, was rehearsed in successive official EU reports and the subject matter of academic and policy debates (summarized in Vandenbroucke et al. 2018). The focus on unemployment insurance is not happenstance. Unemployment insurance supports purchasing power of citizens in a recession, and it is therefore an automatic stabilizer par excellence. Historically, unemployment insurance was a crucial building block in the development of welfare states, and was often established in moments of major economic crisis (Rehm 2016). It is therefore unsurprising that the Great Recession has triggered debate about an EMU-wide support for national unemployment benefit schemes. In today's EU, assigning a role to the EU in the realm of unemployment insurance remains politically an uphill battle. Given the political resistance against EU cross-border risk sharing, it is important to understand citizens' attitudes towards such ideas. Sensitive issues in European debates about risk sharing concern, among others, the conditions for European support for member states, the degree to which permanent redistribution might emerge 
between member states, and the impact on taxation. These issues are dealt with in our research. The emphasis on design questions differentiates it from other studies on EU-wide solidarity that test general predispositions to share resources across borders in various circumstances of need, or relatively broad policy orientations. Research on general attitudes towards European solidarity yields mixed results: some studies find considerable support for EU-wide cross-border solidarity (Ferrera and Pellegata 2017; Gerhards et al. 2018), while other studies come to more nuanced conclusions (Lahusen and Grasso 2018) or find that public support depends heavily on the domain under review (Genschel and Hemerijck 2018).

Research on public support for national unemployment benefits emphasizes self-interest, notably, whether individuals can expect to be net beneficiaries or net contributors, given their employment status (Naumann et al. 2016), risk profile and income level (Rehm 2016), and the role of social justice perceptions such as egalitarianism and the 'deservingness' of the unemployed (Van Oorschot et al. 2017). We combine these social justice considerations in a scale that measures respondents' left-right position, and control for whether they are currently employed.

In the context of the evolving ideological realignment experienced by western societies (Hooghe and Marks 2018; Teney et al. 2014), we examine how the specific design of EUI affects public support, and how this impact varies across people's economic left-right preferences and their orientations towards European integration. On the one hand, the 'old' ideological cleavage between economic left and right may still be an important determinant for preferences towards solidarity, both interacting with (Kleider and Stoeckel 2018) and independently from (Alesina and La Ferarra 2005) actual economic self-interest and status. While ideological positioning may be partially endogenous to economic status, research has shown that it is possible to disentangle the two effects (Margalit 2013). Preferences for national social policy are closely aligned to economic left-right ideology: beyond evaluations of economic self-interest, individuals differ in their views on fairness and equality and on the role of the state in regulating the market. These beliefs influence public support for national social policy (Jaeger 2006) and for international redistribution. Kleider and Stoeckel (2018: 1) find that 'voters' economic leftright orientations are crucial for a fuller understanding of the public conflict over transfers'.

On the other hand, the prospect of European social policy complicates things because it touches upon the 'boundaries of solidarity' (Kuhn and Kamm 2019): social policy is traditionally bound to the nation state, and people disagree whether immigrants or citizens living abroad should also benefit from welfare policies (Pardos-Prado 2020). The literature on welfare chauvinism shows that many citizens are generally supportive of the welfare state but at the same time seek to exclude immigrants from its 
benefits (Mewes and Mau 2013). Kuhn and Kamm (2019) find in a survey experiment in Spain and the Netherlands that economic left-right orientations do not structure solidarity with unemployed people in other EU member states. Hence, support for European unemployment benefits might be more closely linked to the emerging political divide on opening or closing national borders against globalization (Hooghe and Marks 2018; Zürn and de Wilde 2016). Empirical research supports these expectations by showing that support for European integration, European identity and cosmopolitan attitudes more generally, significantly impact on willingness to share resources with people from other countries (Kuhn et al. 2018; Kuhn and Kamm 2019) and international bailout support (Bechtel et al. 2014; Kleider and Stoeckel 2018; Stoeckel and Kuhn 2018). In turn, Franchino and Segatti (2019) find in conjoint experiments conducted in Italy that both left-right ideology and European identity influence support for a fiscal union.

These conflicting results reflect the multidimensional nature of European social policy and underlying concepts of European solidarity. This multidimensionality is salient in the case of unemployment insurance. Hence, existing research on public support for European social policy in general cannot do justice to the complex nature of labour market policies, especially those in multilevel settings such as the EU. Given the multidimensionality of EUI, it is important to study how citizens relate to these different dimensions rather than assessing their general support. Studies on international bailouts in the EU (Bechtel et al. 2014) and labour market policies in Spain (Gallego and Marx 2017) have shown that citizens are sensitive to changes in policy dimensions. We consider six dimensions along which proposals for EUI schemes may vary. Most of these dimensions have consequences both for the domestic policies pursued within countries and for the relationships between the participating countries. For instance, the level of generosity has a potential domestic impact (it sets a minimum floor to the level of national benefits) and a supranational impact (it defines the overall volume of support generated by the European scheme). Or, to take another example, the conditions with which countries have to comply have a potential impact on domestic education policies, but they also affect the legitimacy of the cross-border 'insurance contract' between the participating countries.

Notwithstanding this complexity, one can partition these dimensions into '(mainly) domestic' and '(mainly) cross-border' dimensions (Table 1). We consider generosity, conditions and taxation as predominantly 'domestic' dimensions, since they mainly resonate with well-known domestic policy debates. In contrast, we consider between-country redistribution and the level of administration as 'cross-border' dimensions, since they refer to relationships between countries. 'Domestic' does not imply that a policy is only understood by respondents in terms of what it means in their own country. It means that the respondent's attitude is (expected to be) predominantly triggered by what 
Table 1. Dimensions, levels and expectations of conjoint experiment.

\begin{tabular}{|c|c|c|c|}
\hline Dimensions & Levels & Characterization & Expectation \\
\hline Generosity & $\begin{array}{l}40 \% \\
60 \% \\
70 \%\end{array}$ & $\begin{array}{l}\text { Domestic } \\
\text { dimension }\end{array}$ & $\begin{array}{l}\text { Economic left-right ideology } \\
\text { more important than EU } \\
\text { orientations }\end{array}$ \\
\hline $\begin{array}{l}\text { Country-level } \\
\text { conditionality }\end{array}$ & $\begin{array}{l}\text { No conditions } \\
\text { Education \& training }\end{array}$ & $\begin{array}{l}\text { Domestic } \\
\text { dimension* }\end{array}$ & $\begin{array}{l}\text { Economic left-right ideology } \\
\text { more important than EU } \\
\text { orientations }\end{array}$ \\
\hline $\begin{array}{l}\text { Country-level } \\
\text { redistribution }\end{array}$ & $\begin{array}{l}\text { No long-term redistribution } \\
\text { Long-term redistribution } \\
\text { between all countries } \\
\text { Long-term redistribution } \\
\text { from rich too poor } \\
\text { countries }\end{array}$ & $\begin{array}{l}\text { Cross-border } \\
\text { dimension }\end{array}$ & $\begin{array}{l}\text { EU orientations more } \\
\text { important than economic } \\
\text { left-right ideology }\end{array}$ \\
\hline Taxation & $\begin{array}{l}\text { No increase in taxation } \\
0,5 \% \text { for everyone } \\
1 \% \text { for the rich }\end{array}$ & $\begin{array}{l}\text { Domestic } \\
\text { dimension }\end{array}$ & $\begin{array}{l}\text { Economic left-right ideology } \\
\text { more important than EU } \\
\text { orientations }\end{array}$ \\
\hline Governance & $\begin{array}{l}\text { European governance } \\
\text { National governance }\end{array}$ & $\begin{array}{l}\text { Cross-border } \\
\text { dimension }\end{array}$ & $\begin{array}{l}\text { EU orientations more } \\
\text { important than economic } \\
\text { left-right ideology }\end{array}$ \\
\hline $\begin{array}{l}\text { Individual } \\
\text { conditionality }\end{array}$ & $\begin{array}{l}\text { No conditions } \\
\text { Accept any job } \\
\text { Accept any job \& apply once } \\
\text { a week }\end{array}$ & $\begin{array}{l}\text { Domestic } \\
\text { dimension }\end{array}$ & $\begin{array}{l}\text { Economic left-right ideology } \\
\text { more important than EU } \\
\text { orientations }\end{array}$ \\
\hline
\end{tabular}
* since this dimension involves a conditionality that is bestowed over the community, rather than the indi-
vidual, it can be equally argued that it constitutes a cross-border dimension.

they think about the intrinsic value of the policy (its beneficial effect) qua domestic policy per se. A dimension is 'cross-border' if the respondent's attitude to this dimension is (expected to be) predominantly triggered by considerations about relations between countries. Admittedly, the distinction is not always clear-cut; in Table 1 we indicate that the conditions with respect to training and activation which countries have to comply with can arguably be classified as a 'cross-border' dimension rather than a 'domestic' dimension. Table 1 provides an overview of this characterization of our dimensions and states our expectations.

We expect that these two groups of dimensions interact differently with economic ideology and support for European integration. Cross-border dimensions speak directly to the latter. It is not only plausible that pro-European individuals are more supportive of between-country redistribution and supranational governance than eurosceptics. It is moreover reasonable to expect that the individual's attitude towards the EU plays a greater role in structuring the impact of these cross-border dimensions than economic ideology.

H.1.1. Citizens' orientations towards European integration influence the impact of 'cross-border' dimensions of the policy design (between-country redistribution and level of administration) on their support for EUI more strongly than does their position on the economic left-right dimension. 
On the other hand, the 'domestic' dimensions tie into long-standing conflicts over national redistribution and speak therefore directly to economic ideology. We therefore expect that preferences on domestic dimensions are more influenced by economic ideology than by EU orientations. Individuals with a left-wing economic ideology will value the domestic redistributive character of the policy packages. Similarly, individuals with right-wing economic attitudes will prefer less generous, more conditional programmes.

H.1.2. Citizens' positions on the economic left-right dimension influence the impact of 'domestic' dimensions of the policy design (generosity, conditions with respect to training, education and activation, and taxation) on their support for the policy more strongly than respondents' orientation towards European integration.

\section{Research design}

\section{The conjoint experiment}

We conducted a conjoint experiment embedded in an online survey among 19,500 respondents in 13 EU member states: Austria, Belgium, Denmark, Estonia, Finland, France, Germany, Hungary, Ireland, Italy, Netherlands, Poland, and Spain. These countries vary with respect to welfare state models, past economic performance, geographical location, and euro zone membership. Fieldwork was conducted by the survey company IPSOS and took place in October and November 2018.

Conjoint analysis is increasingly used to analyse preferences on multidimensional issues (Franchino and Segatti 2019; Gallego and Marx 2017; Hobolt and Rodon 2020). In general, respondents are asked to choose between different profiles representing, for example, different policy packages. Each profile varies across a series of dimensions, which can take different values.

Our conjoint analysis is introduced by a short information on the context and aim of ensuring sustainable unemployment benefits in countries facing crises (appendix 1, Figure 1). The conjoint itself varies across 6 dimensions (appendix 1, Table 1), which reflect to a large extent the ongoing debate on actual policy proposals (Vandenbroucke et al. 2018). The different levels of these dimensions match conceivable policy variations and allow for the analysis of fundamental political attitudes. Each respondent evaluates three pairs of policy proposals by indicating which of the two proposals they prefer, and by rating each proposal individually. Hence, they evaluate six proposals in total. Both the selection (i.e., combination of dimensions) and order of the proposals are completely randomized. ${ }^{1}$

The first dimension concerns the percentage of the last wage of the unemployed (or 'replacement rate') insured by the supranational scheme, and it 
features three levels $(40 \%, 60 \%, 70 \%)$. This dimension hence captures the generosity of the scheme. In some countries, values may include a lower replacement rate than what is currently insured by domestic schemes. In the framing, we clarify that countries would always be able to provide higher benefits if they so wish, but at their own expenses. In other words, the scheme creates a common floor to the generosity of national benefit levels across participating countries.

The second dimension captures country-level conditionality, i.e., whether countries must fulfil some conditions to receive the funding. The question is whether respondents prefer a simple benefit scheme or schemes that include social investment. The dimension is structured on two levels ('no conditions', and 'education and training'). The third dimension concerns individual-level conditionality and captures preferences towards conditionality with regard to activation policies, focusing on job-search effort. This dimension features three possible levels: 'no conditions', 'accept any suitable job offer or lose the benefit', and 'apply for at least one job per week, and accept any suitable job offer, or lose the benefit'.

The fourth dimension refers to between-country redistribution. While some schemes involve no long-term redistribution, others imply that some countries become net beneficiaries from the scheme, while others become net contributors. Three levels are included. In the first level ('insurance option'), no redistribution is possible in the long run: the support that countries can receive is capped by their long-term contribution. In the second option ('tolerant option') all countries can receive more from the scheme than what they paid in if necessary. Finally, in the third option ('redistributive option'), poor countries will in the long run be net beneficiaries of the scheme (on purpose).

The fifth dimension concerns the administration of the scheme: while all schemes concern a European policy, the two levels capture whether national administrations or an EU body implement the scheme. The last dimension refers to the impact on taxation in the respondent's country. Three levels are possible: 'no impact'; 'taxes will increase for everyone by $0.5 \%$ of their income', and 'taxes will increase by $1 \%$ of the income, only for the rich'.

In each country, a random sample of 1,500 individuals has been drawn. Quotas for age, gender, education and regional distribution ensure that the final sample follows the population closely, with less than $2 \%$ discrepancy for each demographic category in most countries, and no country with any demographic distribution deviating from the population distribution more than $4 \%$. Surveys were translated into the main languages of each country. ${ }^{2}$ We restrict the sample to respondents who have passed an attention check in the final question of the survey, and to respondents who did not give more than one set of inconsistent answer patterns in the conjoint experiment. $^{3}$ This yields an analytical sample of 93,612 observations. 


\section{Operationalization}

\section{Dependent variables}

The survey experiment includes two possible dependent variables (DVs): the binary package choice, in which respondents have to indicate which of the two packages they prefer, and the ordered scale package score, in which individuals have to evaluate each package. We test our hypotheses with regard to the score variables. To ensure that our estimates remain stable across modelling variations, we run robustness checks that alter (1) the sample composition (including inconsistent and inattentive individuals), (2) the dependent variable (package choice, package score), (3) the control variables, (4) the estimation methods (OLS, Logit, Multilevel Mixed Effects) and (5) the multilevel embedding of the model (using individuals, countries and choice-pairings as levels). Appendix 5e reports these robustness checks for model B1 (Full Interaction Model). ${ }^{4}$

\section{Independent variables}

To measure economic left-right ideology, we construct a composite indicator including 4 elements on the economic left-right divide: the opinion on government responsibility for the unemployed, on income redistribution, on business regulation, and on the unemployed. These standardized items scale just enough together (Cronbach alpha 0.53). Appendix $3 \mathrm{~b}$ provides question wording and robustness indicators.

To capture orientations towards European integration, we construct a scale using 5 elements: European identification, importance of well-being of other Europeans, trust in the EU, trust in EU leaders, and support for membership. These standardized items scale quite well (Cronbach alpha 0.77). Appendix $3 \mathrm{~b}$ provides question wording and statistics on the indicator's robustness.

\section{Control variables}

Our models account for gender, age and education (standardized by the 9 ISCED-11 categories), household income, ${ }^{5}$ and include a dummy variable for being currently unemployed. We include country dummies in all specifications to account for country-level variability.

\section{Results}

\section{Split-sample approach}

Appendix 4a shows a general assessment of the traction of each of the experimental dimensions; however, a more detailed analysis of the experiment is beyond the scope of this paper. Instead, we first test our hypotheses by splitting the sample in subsamples that cluster the respondents according to their economic ideology and orientation towards European integration. We look at 
split samples to explore differences between groups in the causal effect of the EUI dimensions on preferences (Leeper et al. 2019). We partition the respondents into two groups with opposite attitudes, and we apply a composite scale to gauge economic ideology and orientation towards Europe, creating in total four subsamples. ${ }^{6}$ Since we aim to capture significant differences in attitudes on the left/right and European scale, we restrict our analysis to respondents whose score is larger than one standard deviation above/ below the mean. ${ }^{7}$

Testing our hypotheses in a split-sample approach involves three steps. The first step is to estimate, for each subsample, the impact of variations across our six dimensions on the level of support for the policy. All models (models 1-4 Table 2) use a simple OLS estimator in the score variable; they include robust standard errors clustered at the individual level, and control for age, gender, education, income and country. ${ }^{8}$ Model 1 and 2 concern, respectively, individuals with high and low scores on the composite leftright scale, while models 3 and 4 focus on individuals with high and low scores on the scale that measures orientation towards European integration. Thus, we obtain coefficients for the estimated impact of variations in the policy. For instance, in model 1 (left-wing respondents), the coefficient for a generosity level of $60 \%$ is equal to 0.347 , which means that, ceteris paribus, the level of support for the policy among such respondents increases with 0.347 when the generosity shifts from $40 \%$ to $60 \%$. In model 2 (respondents not in favour of redistribution), the same coefficient is only 0.082 . Hence, there is a substantial difference in the impact of such variation in generosity between the respondents examined in model 1 and the respondents examined in model 2: this impact is clearly sensitive to their position on the left/ right scale.

Our second step is to measure the degree of sensitivity; we do this by calculating the absolute difference between the two coefficients; in the case of a shift in generosity from $40 \%$ to $60 \%$, the absolute difference between the coefficients in models $1-2$ is 0.265 . The same calculation for models $3-4$, which are based on attitudes towards European integration, reveals an interesting contrast. The difference in coefficients between model 3 (pro-European respondents) and model 4 (eurosceptics) is only 0.05: the impact of this increase in generosity is not very sensitive to attitudes towards other Europeans.

In a third step we systematically compare the degree of sensitivity, as measured by absolute differences in coefficients, between a clustering of the population based on economic ideology, and a clustering of the population based on orientation towards European integration. In the example above, the absolute difference between models 1 and $2(0.265)$ is much larger than the absolute difference between models 3 and 4 (0.05). Put differently, the impact of a shift in generosity from $40 \%$ to $60 \%$ is more sensitive to 
Table 2. Sensitivity to policy variation, tested via split-sample models.

\begin{tabular}{|c|c|c|c|c|c|c|c|c|}
\hline & & \multicolumn{4}{|c|}{ Main models } & \multicolumn{3}{|c|}{ Hypothesis testing } \\
\hline & & $\begin{array}{l}\text { model } 1 \\
\text { left-wing } \\
\text { subgroup }\end{array}$ & $\begin{array}{l}\text { model } 2 \\
\text { right-wing } \\
\text { subgroup }\end{array}$ & $\begin{array}{c}\text { model } 3 \\
\text { pro-European } \\
\text { subgroup }\end{array}$ & $\begin{array}{c}\text { model } 4 \\
\text { anti-European } \\
\text { subgroup }\end{array}$ & $\begin{array}{c}\text { C: abs. } \\
\text { difference 1-2 }\end{array}$ & $\begin{array}{c}\text { D. abs. } \\
\text { difference 3-4 }\end{array}$ & hypothesis \\
\hline \multirow[t]{2}{*}{$\begin{array}{l}\text { Generosity (expectation: } \\
\text { domestic) }\end{array}$} & $60 \%$ & $\begin{array}{l}0.347 \\
(0.024)^{* * *}\end{array}$ & $\begin{array}{l}0.082 \\
(0.022)^{* *}\end{array}$ & $\begin{array}{l}0.281 \\
(0.025)^{* * *}\end{array}$ & $\begin{array}{l}0.231 \\
(0.023)^{* * *}\end{array}$ & 0.2655 & 0,05 & $c>d$ \\
\hline & $70 \%$ & $\begin{array}{l}0.514 \\
(0.025)^{* * *} \\
\end{array}$ & $\begin{array}{c}0.033 \\
(0.023) \\
\end{array}$ & $\begin{array}{l}0.368 \\
(0.027)^{* * *}\end{array}$ & $\begin{array}{l}0.286 \\
(0.025)^{* * *}\end{array}$ & 0,481 & 0.061 & $c>d$ \\
\hline $\begin{array}{l}\text { Country-level conditionality } \\
\text { (expectation: domestic) }\end{array}$ & $\begin{array}{l}\text { Education \& } \\
\text { training }\end{array}$ & $\begin{array}{l}0.152 \\
(0.019)^{* * *}\end{array}$ & $\begin{array}{l}0.141 \\
(0.018)^{* * *}\end{array}$ & $\begin{array}{l}0.187 \\
(0.020)^{* * *}\end{array}$ & $\begin{array}{l}0.13 \\
(0.018)^{* * *}\end{array}$ & 0.011 & 0,057 & $c>d$ \\
\hline \multirow[t]{2}{*}{$\begin{array}{l}\text { Between-country redistribution } \\
\text { (expectation: cross-border) }\end{array}$} & $\begin{array}{l}\text { Between all } \\
\text { countries }\end{array}$ & $\begin{array}{l}0.058 \\
(0.023)^{* *}\end{array}$ & $\begin{array}{l}-0.043 \\
(0.022)^{* *}\end{array}$ & $\begin{array}{l}0.094 \\
(0.025)^{* * *}\end{array}$ & $\begin{array}{c}-0.035 \\
(0.023)\end{array}$ & 0.101 & 0,129 & $d>c$ \\
\hline & $\begin{array}{l}\text { From rich too } \\
\text { poor }\end{array}$ & $\begin{array}{l}0.102 \\
(0.023)^{* * *}\end{array}$ & $\begin{array}{l}-0.043 \\
(0.022)^{*}\end{array}$ & $\begin{array}{l}0.124 \\
(0.025)^{* * *}\end{array}$ & $\begin{array}{l}-0.055 \\
(0.022)^{* *}\end{array}$ & 0.145 & 0,179 & $d>c$ \\
\hline \multirow[t]{3}{*}{ Taxation (expectation: domestic) } & $\begin{array}{l}0,5 \% \text { for } \\
\text { everyone }\end{array}$ & & & -0.077 & & 0.070 & 0,078 & $c>d$ \\
\hline & & $(0.023)^{* * *}$ & $(0.022)^{* * *}$ & $(0.024)^{* * *}$ & $(0.023)^{* * *}$ & & & \\
\hline & $1 \%$ for the rich & $\begin{array}{c}0.014 \\
(0.023) \\
\end{array}$ & $\begin{array}{l}-0.210 \\
(0.023)^{* * *}\end{array}$ & $\begin{array}{l}-0.056 \\
(0.025)^{* * *}\end{array}$ & $\begin{array}{l}-0.064 \\
(0.022)^{* * *}\end{array}$ & 0,224 & 0,008 & $c>d$ \\
\hline $\begin{array}{l}\text { Governance (expectation: cross- } \\
\text { border) }\end{array}$ & $\begin{array}{l}\text { National } \\
\text { governance }\end{array}$ & $\begin{array}{l}0.06 \\
(0.019)^{* * *}\end{array}$ & $\begin{array}{l}0.07 \\
(0.02)^{* * *}\end{array}$ & $\begin{array}{l}-0.126 \\
(0.021)^{* * *}\end{array}$ & $\begin{array}{l}0.221 \\
(0.020)^{* * *}\end{array}$ & 0,01 & 0.347 & $d>c$ \\
\hline \multirow[t]{5}{*}{$\begin{array}{l}\text { Individual-level conditionality } \\
\text { (expectation: domestic) }\end{array}$} & Accept any job & $\begin{array}{l}-0.126 \\
(0.026)^{* * *}\end{array}$ & $\begin{array}{l}0.426 \\
(0.024)^{* * *}\end{array}$ & $\begin{array}{l}0.196 \\
(0.027)^{* * *}\end{array}$ & $\begin{array}{l}0.099 \\
(0.025)^{* * *}\end{array}$ & 0,552 & 0,097 & $c>d$ \\
\hline & $\begin{array}{l}\text { Accept any job \& } \\
\text { apply }\end{array}$ & $\begin{array}{l}-0.172 \\
(0.026)^{* * *}\end{array}$ & $\begin{array}{l}0.450 \\
(0.024)^{* * *}\end{array}$ & $\begin{array}{l}0.178 \\
(0.027)^{* * *}\end{array}$ & $\begin{array}{l}0.084 \\
(0.025)^{* * *}\end{array}$ & 0,622 & 0,094 & $c>d$ \\
\hline & Coefficients of cor & trol variables o & & & & & & \\
\hline & $R^{2}$ & 0.08 & 0.07 & 0.06 & 0.05 & & & \\
\hline & $N$ & 13,968 & 11,082 & 11,724 & 14,364 & & & \\
\hline
\end{tabular}

Notes: Figures are coefficients of OLS models with individual-robust standard errors. SEs in parenthesis $p<0.1 ;{ }^{* *} p<0.05 ;{ }^{* * *} p<0.01$. Models control for age, gender, education, income and country. The last two columns measure the degree of sensitivity by the absolute value of the difference in coefficients over subsample models; grey shade: hypothesis confirmed; no grey shade: hypothesis rejected. 
economic ideology than to orientations towards European integration, which confirms Hypothesis 1.2. Table 2 presents the results for all dimensions for all subsamples. The seventh column of Table 2 indicates our expectations with regard to the sensitivity of the impact of policy variation along the dimensions. We expect that for generosity, country-level conditionality and individual conditionality the sensitivity over model 1-2 is larger than the sensitivity over model 3-4. We expect the opposite for between-country redistribution and governance. A grey shade indicates that the hypothesis is supported by the figures.

This analysis supports our hypotheses, except with regard to education and training and a linear increase in taxation. The sensitivity to the education and training condition is larger when we divide the population on the basis of a pro/anti-European scale, than the sensitivity when we divide the population on the basis of economic ideology. With regard to taxation, it turns out that a distinction must be made between redistributive taxation (for which our hypothesis $\mathrm{H} 1.2$ holds) and a linear increase in taxation for everybody: the sensitivity to a linear increase (as compared to no change) is the same, whether we divide the population in terms of economic ideology or in terms of attitudes towards European integration.

\section{Full interaction models and marginal effects}

Model 3 (Table 3) estimates a full-interaction model by including the interactions of dimensions with the economic left-right scale and the EU-orientations scale. This allows us to analyse how the intensity of different forms of polarization affects the impact of the dimensions on preferences. Furthermore, a full interaction model allows to assess how preferences evolve when we account for variations in both dimensions of polarization simultaneously; both provide information that would remain out of reach when splitting the sample. Again, all models are OLS with clustered standard errors at individual level. Results are consistent across a number of robustness checks (appendix 5 and 6; for details, see footnote 1).

The first column of Table 3 presents the main effect, the second column the interaction effect with economic ideology, and the third column the interaction effect with EU orientations. Similarly, the panels of Figure 1 reproduce the predicted interaction effects between the two scales and the policy dimensions, for each of the levels of the scales (from -3 - right wing, and anti-EU) to 3 (left wing, and pro-EU).

The results of model 3 align with the result of the split-sample analysis; the direction and relative size of average effects is equivalent. The analysis of the marginal effects yields additional insight on the interaction of cross-border redistribution with the two scales (panels 5 and 6 in Figure 1). As the placement of an individual approaches the extreme on both scales, the difference 
Table 3. Full interaction models.

\begin{tabular}{|c|c|c|c|c|}
\hline & \multicolumn{3}{|c|}{ model 3: full interaction (scale) } \\
\hline & & $\begin{array}{l}\text { main } \\
\text { effect }\end{array}$ & $\begin{array}{l}\text { interaction (left- } \\
\text { right scale) }\end{array}$ & $\begin{array}{l}\text { interaction (EU } \\
\text { orientations scale) }\end{array}$ \\
\hline \multirow{5}{*}{ Generosity } & Left-right scale & $\begin{array}{c}0.036 \\
(1.70)^{*}\end{array}$ & & \\
\hline & EU polity scale & $\begin{array}{l}0.099 \\
(5.22)^{* * *}\end{array}$ & & \\
\hline & $40 \%$ & n/a (base level) & & \\
\hline & $60 \%$ & $\begin{array}{c}0.217 \\
(23.72)^{* * *}\end{array}$ & $\begin{array}{c}0.163 \\
(10.78)^{* * *}\end{array}$ & $\begin{array}{c}0.014 \\
(1.06)\end{array}$ \\
\hline & $70 \%$ & $\begin{array}{c}0.277 \\
(28.69)^{* * * *}\end{array}$ & $\begin{array}{c}0.261 \\
(16.59)^{* * *}\end{array}$ & $\begin{array}{l}0.020 \\
(1.4)\end{array}$ \\
\hline \multirow{3}{*}{$\begin{array}{l}\text { Country-level } \\
\text { conditionality }\end{array}$} & No conditions & & $\mathrm{n} / \mathrm{a}$ (base level) & \\
\hline & Education \& training & $\begin{array}{c}0.155 \\
(20.97)^{* * *}\end{array}$ & $\begin{array}{c}0.002 \\
(0.18)\end{array}$ & $\begin{array}{l}0.037 \\
(3.45)^{* * *}\end{array}$ \\
\hline & Pure insurance & $\mathrm{n} / \mathrm{a}$ (base level) & & \\
\hline \multirow[t]{2}{*}{$\begin{array}{l}\text { Country-level } \\
\text { redistribution }\end{array}$} & All countries & $\begin{array}{l}0.019 \\
(2.11)^{* *}\end{array}$ & $\begin{array}{l}0.045 \\
(3.10)^{* * *}\end{array}$ & $\begin{array}{l}0.059 \\
(4.49)^{* * *}\end{array}$ \\
\hline & From rich to poor & $\begin{array}{l}0.024 \\
(2.64)^{* * *}\end{array}$ & $\begin{array}{c}0.080 \\
(5.51)^{* * *}\end{array}$ & $\begin{array}{c}0.069 \\
(5.31)^{* * *}\end{array}$ \\
\hline \multirow[t]{3}{*}{ Taxation } & No taxation & $\mathrm{n} / \mathrm{a}$ (base level) & & \\
\hline & $0,5 \%$ for everyone & $\begin{array}{l}-0.136 \\
(15.20)^{* * *}\end{array}$ & $\begin{array}{l}0.032 \\
(2.23)^{* *}\end{array}$ & $\begin{array}{l}0.026 \\
(1.97)^{* *}\end{array}$ \\
\hline & $1 \%$ for the rich & $\begin{array}{l}-0.067 \\
(7.52)^{* * *}\end{array}$ & $\begin{array}{l}0.11 \\
(7.47)^{* * *}\end{array}$ & $\begin{array}{l}0.006 \\
(0.43)\end{array}$ \\
\hline \multirow[t]{2}{*}{ Governance } & EU governance & n/a (base level) & & \\
\hline & National Governance & $\begin{array}{l}0.058 \\
(7.52)^{* * *}\end{array}$ & $\begin{array}{c}-0.006 \\
(0.46)\end{array}$ & $\begin{array}{l}-0.148 \\
(12.65)^{* * *}\end{array}$ \\
\hline \multirow{11}{*}{$\begin{array}{l}\text { Individual } \\
\text { conditionality }\end{array}$} & No conditions & $\mathrm{n} / \mathrm{a}$ (base level) & & \\
\hline & Accept any offer & $\begin{array}{l}0.168 \\
(16.96)^{* * *}\end{array}$ & $\begin{array}{l}-0.292 \\
(18.02)^{* * *}\end{array}$ & $\begin{array}{l}0.079 \\
(5.52)^{* * *}\end{array}$ \\
\hline & $\begin{array}{l}\text { Accept any offer \& apply } \\
\text { once a week }\end{array}$ & $\begin{array}{c}0.144 \\
(14.26)^{* * *}\end{array}$ & $\begin{array}{l}-0.336 \\
(20.8)^{* * *}\end{array}$ & $\begin{array}{l}0.079 \\
(5.44)^{* * *}\end{array}$ \\
\hline & Low education & $\begin{array}{c}0.054 \\
(4.44)^{* * *}\end{array}$ & & \\
\hline & $\begin{array}{l}\text { Logged household } \\
\text { income }\end{array}$ & $\begin{array}{l}-0.039 \\
(3.93)^{* * *}\end{array}$ & & \\
\hline & Currently unemployed & $\begin{array}{l}-0.045 \\
(2.28)^{* *}\end{array}$ & & \\
\hline & Age & $\begin{array}{c}-0.010 \\
(1.66)^{*}\end{array}$ & & \\
\hline & Female & $\begin{array}{l}0.010 \\
(1.11)\end{array}$ & & \\
\hline & Constant & $\begin{array}{c}3.273 \\
(30.51)^{* * *}\end{array}$ & & \\
\hline & R2 & 0.07 & & \\
\hline & $\mathrm{N}$ & 78270 & & \\
\hline
\end{tabular}

Notes: Figures are coefficients of one OLS model with individual- robust standard errors. T-statistics in parentheses. ${ }^{*} p<0.1 ;{ }^{* *} p<0.05 ;{ }^{* * *} p<0.01$. First column shows main effects, second and third column show interaction effects with scales. Coefficients of country-fixed effects not shown.

between the two effects increases. However, this difference is significant only for individuals characterized by extreme attitudes, and only holds for preferences with regard to the 'tolerant' forms of redistribution. H1.1. is therefore rejected with regard to the cross-country redistribution dimension, while it 


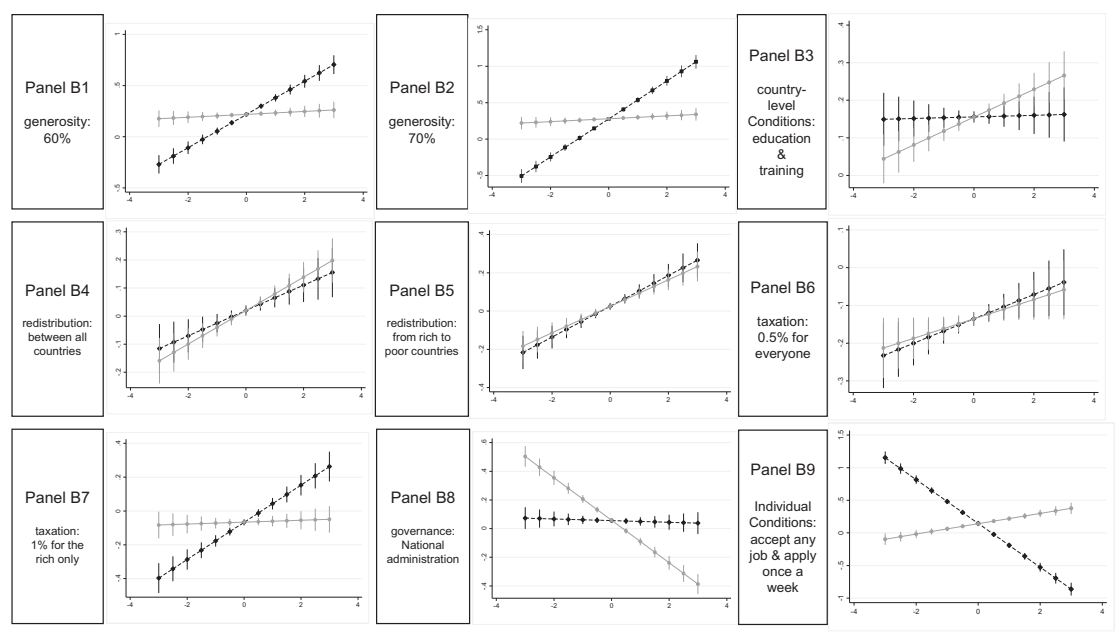

Figure 1. Marginal effects for left-right scale in black. Marginal effects for EU orientations scale in light grey.

holds for the governance dimension. When redistribution is constrained to take place from rich to poor countries, economic ideology plays as much a role as EU attitudes. In fact, in this specific dimension, it is the combination of the two scales that plays the most important role, with left-wing, pro-Europeans strongly supporting cross-country redistribution, and right-wing antiEuropeans strongly opposing it. This suggests that while in general, preferences concerning some design elements are more influenced by economic ideology, others are more influenced by attitudes towards integration, genuine cross-country redistributive issues activate both sensibilities and polarize individuals in yet a new way.

In sum, both the split-sample models and the full interaction models confirm our expectations on the relative effect of economic ideology and support for the EU on the impact of the policy dimensions on support, with two exceptions: with regard to redistribution from rich to poor countries, economic ideology plays as much a role as attitudes towards the EU; with regard to the conditions for education and training policies, the position on the EU polity cleavage is more important than the position on the left-right scale.

\section{Conclusion}

Public opinion towards European unemployment risk sharing is poorly understood. An original survey experiment fills this lacuna by exploring how respondents' economic ideology and orientations towards European integration influence preferences for alternative designs of EUI. 
We start from the idea that social policies in general, and EUI in particular, are multidimensional constructs. Therefore, different features of such schemes may gather support of different groups of people, depending on how a specific policy design conforms or conflicts with the individuals' political orientations and how the scheme is expected to impact them personally. To better understand the multidimensional nature of European social policy, we deploy an original conjoint experiment modelling EUI across 6 dimensions. A total of 19,500 individuals across 13 countries were surveyed, expressing their preferences for designs varying - on the one hand - on domestic features of the schemes, such as the degree of generosity, country-level conditions with regard to education and training, the taxation impact, and individual conditions with regard to job search effort; and - on the other hand - on cross-border features of the schemes, such as the governance and the presence of long-term redistributive effects across countries.

We expect economic ideology (ranging from economic left to economic right) to be more strongly associated with the domestic features while we expect attitudes towards European integration to be more strongly associated with the cross-border features. Results confirm most of our expectations, although in a more nuanced way than originally envisaged. On the one hand, the economic left-right position plays a key role in determining the impact of generosity, redistributive taxation, and individual conditionality for package support; on the other hand, the individual's attitudes towards European integration strongly moderates the traction that national governance versus EU governance has on package support. One expectation is clearly rejected: the country-level conditionality with regard to education, which was expected to be more strongly associated with economic ideology, rather than with EU orientations, turned out to be strongly moderated by EU attitudes instead. This effect may have two sources. First, citizens favouring European integration tend to have higher levels of education (Hakhverdian et al. 2013). Hence, they may value education more, and be more sensitive to countrylevel investment in education and training. Second, the country-level nature of this conditionality may speak directly to the world view of pro-European individuals. In this understanding of what motivates our respondents, it would be the 'cross-border' aspect of this dimension that speaks -in a positive sense - to pro-European individuals more than to other individuals. Either way, EU orientations are far more important than economic left-right placement in determining the impact of the country-level conditionality with regard to education and training on package choice. Finally, our analysis provides insufficient evidence to support our hypothesis for country-level redistribution. Although the average effects are slightly larger for European attitudes than for the economic variables, as expected, and although the slope of the marginal effects for the European scale is steeper than the slope of the marginal effects of the economic scale, the difference is not 
statistically significant. The highest level of polarization over the cross-border redistribution dimension is yielded by the combination of both scales: leftwing pro-Europeans strongly support between-country redistribution, while right-wing anti-Europeans strongly oppose it. This finding resonates with a recent study by Franchino and Segatti (2019) that finds that high-income, right-wing individuals with a weak European identity and negative assessment of EU membership are most likely to oppose a European fiscal union. It also speaks to the contribution by Hobolt and Rodon (2020) on EU issue voting who find that a candidate's position on Brexit is as relevant to voters as their economic left-right position.

Some limitations of this study invite caution in interpreting the results. First, to maintain simplicity and avoid cognitive biases, policy variations included here test only a sub-sample of the total policy variations possible in a EUI scheme; there might be other policy packages (not tested in the experiment) that gather even more support of those tested. Second, the explained variance of most models is rather limited ( $r$-square rarely over $8 \%)$, suggesting that some underlying phenomena (possibly macro-level) are currently lacking in our analysis. The small number of countries (13) limits the extent to which multilevel analysis can be used in this regard: future work on this dataset will use the regional level to model the macro-level conditions in which respondents are immerged. In this context, the use of post-stratification weights can be used to correct for minor deviations in the sample from the targeted quotas. Finally, in practice, the introduction of EUI would be a major development for the EU, tailored to the perceived needs of the weaker countries. As such, it is unlikely that it would be introduced without being part of a larger 'grand bargain', for instance including tighter control on fiscal policy or strengthened macroeconomic coordination. Since such negotiating exchanges are impossible to model within this experiment, it is possible that support for the scheme in net-contributor countries is underestimated in our results, while support for the scheme in net-recipient countries could be over-estimated. These limitations notwithstanding, this article shows that different patterns of polarization can coexist in determining preferences for multilevel social policy, and that different dimensions of composite multilevel social policies speak to different sensibilities of individuals with regard to their economic ideologies and their positioning on European integration.

\section{Notes}

1. The order of the dimensions was randomized, with the following exception: country-level conditionality and country-level redistribution were presented following each other for ease of understanding. 
2. The Belgian survey was translated into French and Dutch; in the Spanish region of Catalonia, it was offered in Spanish and Catalan; Estonians could choose between Estonian and Russian.

3. $12 \%$ of the respondents gave an inconsistent answer (the choice of policy $A$ over B, whilst the respondent expresses more absolute support for B) in one of the three sets of policy alternatives; $2.6 \%$ gave more than one inconsistent answer.

4. The baseline is a full interaction model (model 3 ) on the Score variable, excluding inattentive and inconsistent individuals, with controls. Appendix $5 \mathrm{a}$ includes inattentive and inconsistent respondents; $5 \mathrm{~b}$ excludes controls, and $5 \mathrm{c}$ controls for fear of becoming unemployed, preference for migration controls, and conservative gender views. These variations are reproduced with the Choice variable (appendix $5 d, 5 e, 5 f$ ). Model 3 is reproduced with 2 different multilevel embeddings ( $5 g$ \& $5 \mathrm{~h}$ ). Annex 6 reports model 3 for each country. The same robustness checks for the split-sample models are available upon request.

5. Household income is log of the middle income of the decile to which the respondent belongs (income after tax and compulsory deductions, from all sources).

6. Appendix $4 \mathrm{~b}$ shows additional analyses using single items rather than scales. They largely align with the results shown here.

7. The scales being standardized, the mean is about 0 in both cases.

8. Appendix $4 \mathrm{c}$ report estimates using logit models instead of OLS (also for individual-variable models estimated in appendix $4 b$ ).

\section{Acknowledgements}

We thank Brian Burgoon, Sara Hobolt, Sergi Pardos, Toni Rodon, the participants at the workshop 'Domestic contestation of the European Union', London School of Economics and Political Science, December 2018, and the two anonymous reviewers for very helpful comments. Sven Hegewald and David van der Duin provided excellent research assistance. The usual disclaimers apply.

\section{Disclosure statement}

No potential conflict of interest was reported by the authors.

\section{Funding}

This research was supported by KU Leuven (Belgium) and Istituto Nazionale per I'Analisi delle Politiche Pubbliche (INAPP, Italy). Theresa Kuhn acknowledges funding from the Dutch Research Council (grant nr. 451-13-029).

\section{Notes on contributors}

Theresa Kuhn is Associate Professor in political science at the University of Amsterdam.

Francesco Nicoli is Assistant Professor economic governance at the University of Ghent and affiliated to the Amsterdam Institute of Social Science Research (AISSR).

Frank Vandenbroucke is University Professor at the University of Amsterdam. 


\section{ORCID}

Theresa Kuhn (D) http://orcid.org/0000-0001-8784-1731

\section{References}

Alesina, A. and La Ferrara, E. (2005) 'Preferences for redistribution in the land of opportunities', Journal of Public Economics 89(5-6): 897-931.

Baute, S., Meuleman, B., Abts, K. and Swyngedouw, M. (2018) 'Measuring attitudes towards social Europe: A multidimensional approach', Social Indicators Research 137(1): 353-378.

Bechtel, M.M., Hainmueller, J. and Margalit, Y. (2014) 'Preferences for international redistribution: The divide over the eurozone bailouts', American Journal of Political Science 58(4): 835-856.

European Commission (2017a) 'Reflection paper on the deepening of the economic and monetary union'. COM(2017) 291, 31 May, Brussels: European Commission, available at https://ec.europa.eu/commission/sites/beta-political/files/reflection-paperemu_en.pdf (accessed July 2019).

European Commission (2017b) 'Communication from the Commission to the European Parliament, the European Council, the Council and the European Central Bank. New budgetary instruments for a stable Euro area within the union framework', COM (2017) 8222 Final, 6 December, Brussels: European Commission, available at https://ec.europa.eu/info/sites/info/files/economy-finance/com_822_0.pdf (accessed July 2019).

Ferrera, M. and Pellegata, A. (2017) 'Can economic and social Europe be reconciled? Citizens' view on integration and solidarity', RESCEU Working Paper Series, Milan: University of Milan, February 2017, https://www.centroeinaudi.it/images/ locandine/REScEU_Mass_survey_results_SHORT_VERSION.pdf.

Franchino, F. and Segatti, P. (2019) 'Public opinion on the Eurozone fiscal union: evidence from survey experiments in Italy', Journal of European Public Policy 26(1): 126-148.

Gallego, A. and Marx, P. (2017) 'Multi-dimensional preferences for labour market reforms: a conjoint experiment', Journal of European Public Policy 24(7): 10271047.

Genschel, P. and Hemerijck, A. (2018) 'Solidarity in Europe', Policy Brief School of Transnational Governance 2018/01, Florence: European University Institute. May 2018, https://cadmus.eui.eu/bitstream/handle/1814/53967/STG_PB_2018_01.pdf? sequence $=4 \&$ is Allowed $=\mathrm{y}$.

Gerhards, J., Lengfeld, H., Ignácz, Z.S., Kley, F.K. and Priem, M. (2018) 'How strong is European solidarity?', BSSE Working Paper No. 37, Berlin: Freie Universität Berlin, February 2018, https://www.polsoz.fu-berlin.de/soziologie/arbeitsbereiche/makros oziologie/arbeitspapiere/bsse_37.html.

Hakhverdian, A., Van Elsas, E., Van der Brug, W. and Kuhn, T. (2013) 'Euroscepticism and education: A longitudinal study of 12 EU member states, 1973-2010', European Union Politics 14(4): 522-541.

Hobolt, S. and Rodon, T. (2020) 'Cross-cutting issues and electoral choice: EU issue voting in the aftermath of Brexit', Journal of European Public Policy. doi:10.1080/ 13501763.2019.1701535

Hooghe, L. and Marks, G. (2018) 'Cleavage theory meets Europe's crises: Lipset, Rokkan, and the transnational cleavage', Journal of European Public Policy 25(1): 109-135. 
Jaeger, M.M. (2006) 'What makes people support public responsibility for welfare provision: self-interest or political ideology? A longitudinal approach', Acta Sociologica 49(3): 321-338.

Kleider, H. and Stoeckel, F. (2018) 'The politics of international redistribution: Explaining public support for fiscal transfers in the EU', European Journal of Political Research 58 (1): $1-26$.

Kuhn, T. and Kamm, A. (2019) 'The national boundaries of solidarity: A survey experiment on solidarity with unemployed people in the European Union', European Political Science Review 11(2): 179-195.

Kuhn, T., Solaz, H. and van Elsas, E.J. (2018) 'Practising what you preach: how cosmopolitanism promotes willingness to redistribute across the European Union', Journal of European Public Policy 25(12): 1759-1778.

Lahusen, C. and Grasso, M. (2018) 'Solidarity in Europe: a comparative assessment and discussion', in C. Lahusen and M.T. Grasso (eds), Solidarity in Europe. Citizens' Responses in Times of Crisis, Basingstoke: Palgrave Macmillan, pp. 253-281.

Leeper, T.J., Hobolt, S. and Tilley, J. (2019) 'Measuring subgroup preferences in conjoint experiments', Political Analysis. doi:10.1017/pan.2019.30.

Margalit, Y. (2013) 'Explaining social policy preferences: evidence from the great recession', American Political Science Review 107(1): 80-103.

Mewes, J. and Mau, S. (2013) 'Globalization, socio-economic status and welfare chauvinism: European perspectives on attitudes toward the exclusion of immigrants', International Journal of Comparative Sociology 54(3): 228-245.

Naumann, E., Buss, C. and Bähr, J. (2016) 'How unemployment experience affects support for the welfare state: a real panel approach', European Sociological Review 32(1): 81-92.

Pardos-Prado, S. (2020) 'Labour market deregulation, immigration, and radical right voting', Journal of European Public Policy. doi:10.1080/13501763.2019.1701536

Rehm, P. (2016) Risk Inequality and Welfare States. Social Policy Preferences, Development, and Dynamics, Cambridge: Cambridge University Press.

Stoeckel, F. and Kuhn, T. (2018) 'Mobilizing citizens for costly policies: the conditional effect of party cues on support for international bailouts in the European Union', JCMS: Journal of Common Market Studies 56(2): 446-461.

Teney, C., Lacewell, O.P. and De Wilde, P. (2014) 'Winners and losers of globalization in Europe: attitudes and ideologies', European Political Science Review 6(4): 575-595.

Vandenbroucke, F., Burgoon, B.M., Kuhn, T., Nicoli, F., Sacchi, S., van der Duin, D. and Hegewald, S. (2018) 'Risk sharing when unemployment hits: How policy design influences citizen support for European unemployment risk sharing (EURS)', AISSR Policy Report 1, Amsterdam: Amsterdam Institute for Social Science Research, December 2018, https://aissr.uva.nl/content/news/2018/12/eurs.html.

Van Oorschot, W., Roosma, F., Meuleman, B. and Reeskens, T. (2017) The Social Legitimacy of Targeted Welfare. Attitudes to Welfare Deservingness, Cheltenham: Edward Elgar.

Van Rompuy, H. (2012) 'Towards a genuine economic and monetary union', Report by President of the European Council Herman van Rompuy, Brussels: European Council.

Zürn, M. and de Wilde, P. (2016) 'Debating globalization: cosmopolitanism and communitarianism as political ideologies', Journal of Political Ideologies 21(3): 280-301. 